\title{
Book review: Unsettled: Denial and belonging among White Kenyans by Janet McIntosh
}

$\mathrm{M}$ cIntosh's, Unsettled: Denial and belonging among White Kenyans, is an ethnography of White Kenyan settler descendants who are battling with their identities and sense of belonging in the post-colonial Kenya. The author shares numerous stories of various ordinary interactions with her respondents (aged $20-80$ ), as well as interactions from semistructured and open ended interviews. McIntosh notes that "ethnographies of elite groups are somewhat unusual; most cultural anthropologists prefer to explore the experiences of people who don't have much of a voice" (pg.14), but with this ethnographic account of White settler descendants, the author provides the reader with a critical look into Whiteness and White privilege by documenting how the respondents situate themselves between the colonial past and post-colonial present.

In her opening chapter, Unsettled, McIntosh expands on a phrase she believes best captures the unease of some White Kenyans - moral double consciousness. She takes the stance of other scholars, such as L.M. Alcoff, who have extended the concept of moral double consciousness to include "situations where a privileged social group reckons internally with the judgments of its critics, destabilizing it, even if not critically injuring its members" (pg.6). McIntosh notes how this double consciousness experienced by the colonial Whites causes a morally confusing experience, where inner conflict and self- doubt arises. She goes on to explain how the settler descendants go on to counter their moral double consciousness by introducing the term of structural oblivion.

Structural oblivion is a term coined by McIntosh in order to capture the particular blind spots and dismissals by settler descendants. She defines the term as "a state- a subject position- of ignorance, denial and ideology that emerges from an elite social structural position, and it is constituted by the refusal of certain implications of social structure" (pg.10). McIntosh uses this term throughout the book to highlight the construction of elite ignorance, ideology and self depiction and raise awareness to the fact that elites do not always understand the gravity of that they have simply brushed aside or of that that they do not know, and "they tend not to recognize the machinery of power that has structured their selective lens on the world" (pg.12).

The chapter further offers various notes on her methodology, where she mentions her views and experiences as an ethnographer. Through her selfreflection on her methodology, McIntosh provides prospective ethnographers with a concise guideline and insight into being an ethnographer. McIntosh concludes this chapter by expanding on Kenya's unforgettable past and troubled histories, where she documents a structure that encouraged racism and allows the reader to gain insight on the colonial injustices of the past. She 
explains how this has created a muddle of double consciousness among the White settler descendants who are struggling to situate themselves in an independent Kenya, based on these colonial histories.

In Chapter 2, Loving the Land, McIntosh uses the term of structural oblivion to detail how White settler descendants have created 'blindspots' that enable them to feel more comfortable with the predominantly White land ownership in Kenya. Throughout this chapter, McIntosh shares the romanticized accounts of her respondents in connection to their 'authentic' love for the land, which highlights the fact that many of the White settler descendants know very little of the precolonial methods of land occupation, the details of colonialera land appropriation or even about the ecological facts of precolonial pastoralism. McIntosh makes the point that community based conservation in Kenya, allows White Kenyans to maintain the rights of ownership over the land and wildlife, while feeling at ease with themselves as they perceive themselves to be 'generously' giving back to the Black Kenyans living nearby.

McIntosh points out the collective amnesia her respondents have towards the colonial Masaai land evictions and moves centuries ago. Her respondents use dismissive terminology, "referring to 'uninhabited' or 'empty' land, and erasing human life with a few syllables" (pg.64). Though the use of structural oblivion is clear to rationalize white land ownership, we see the emerging moral double consciousness of the White settler descendants. They appear to differ on how much they are willing to share the resources they have and how to entertain Black Kenyan views about land rights and conservation. What emerges form this is a "framework for fresh questions about how they might situate themselves in the the land that they love when other inhabitants do not always welcome their approach" (pg.53)

Guilt, Chapter 3, expands on the notion of guilt with reference to the case of the White Kenyan farmer accused of manslaughter, Tom Cholmondeley, who in the space of one year, shot and killed two Black Kenyans on his estate, one a game ranger and the other a poacher. In her discussion of the multifaceted nature of guilt, McIntosh states that it was made clear to the settler descendants that due to their collective association to Tom Cholmondeley, that in the court of public opinion, collective and moral guilt had been projected onto them. This caused many of the settler descendants to be ripped out of their structural oblivion, yet there were still those who seem to hide behind their colonial ancestor's alibi of good intentions, and who distance themselves from the collective guilt by keeping their colonial past at arms length.

This chapter captures the "quintessential dilemma for contemporary White Kenyans" (104) living in a nation divided - with some citizens willing to embrace them as part of a diverse Kenya but others indulging "in a keen bigotry of their own, cultivating ethno-tribalism, antagonism and racial essentialism that paints whites as forever interlopers" (104). The White settler descendants may hope for a unified nation that looks past racial and ethnic differences, but as McIntosh states that by practicing this racial and ethnic 'blindness', they are also blinding themselves to the history of inequality that built Kenya.

McIntosh uses the term structural oblivion in reference to the white settler descendants intimate relationships with Black Kenyans and their relationships with their domestic staff 
in the chapter titled Conflicted Intimacies. Her respondents state on multiple occasions that they want to be part of a multicultural Kenya, and shed off the labels of 'spoiled and unhelpful elites', yet "strains of distance, denial and structural oblivion" (pg.150) remain. Her respondents yearning for an integrated Kenya is countered by their hesitation towards interracial romance and their temptation to self-segregate due to 'cultural differences'. With their staff, they wish to be loved by them and claim that they are part of the 'family', yet this relationship is forged upon economical dependency. McIntosh concludes that her respondents may wish to live in a diverse and integrated Kenya, but the "intimacy that they establish with Black Kenyans still seem limited” (pg. 150).

The author touches on issues surrounding language within Chapter 5, Linguistic Atonement, which tells of the action in which the young settler descendants embrace the Kiswahili language and use it in order to create a connection with the Kenya's majority. This offers a "safe symbolic version of social intimacy" (pg.152) and the ability to speak Kiswahili has become important for White Kenyans as they struggle with moral double consciousness and belonging in Kenya. The respondents feel that learning the language will help them to overcome the negative stereotypes of White Kenyans and will allow them to atone for their colonial past. Yet, these connections are limited as linguistic hierarchies are still prevalent, not only amongst White Kenyans, but throughout Kenya's linguistic landscape as English is seen as the language of prestige and is "the paramount language of education, wealth and cosmopolitans while Kiswahili is seen by most as a lingua franca with a nationalist flavor (162)."

In the final chapter, The Occult, McIntosh discusses the White settler descendants positioning towards the occult of the dozens of ethnic groups in Kenya. The author speaks to the colonial erasures and aversion of the occult and its long history of unnerving Whites in Africa. Today, settler descendants are stuck between their inherent feeling of the European sense of rationality and self-determination that they feel is vital in the development of Kenya and their apparent predisposition to these African ideas and their need to show a form of immunity towards them. Some of the settler descendants however, have used the occult to their own benefit even though it goes against the colonial ideals of the White Kenyans and McIntosh mentions that very seldom, they believe that if they do wrong by the Kenyans, that they could invite these forces which might have an impact on their financial being and land ownership. But for most, it seems that the White settler descendants view the occult as a means to assimilate to the life around them, but they still hold on to their European cultural supremacy.

By sharing the voices of the White settler descendants in Kenya, Unsettled: Denial and belonging among White Kenyans offers a new perspective on Whiteness and White privilege and manages to illustrate the plurality of Whiteness in Kenya. The author discusses that "whiteness is centrally understood in terms of system, structures, efforts and subjectivities that retain white control and white privilege" (214), but there is not only one way of being 'White'. The book explored moral double consciousness and shows how White Kenyans, through structural oblivion, have used techniques of erasure and ideologies to legitimize their White privilege and they don't often realize that their ways of life stem from western hegemony, White privilege and colonial mentalities. 
The author poses the question of whether White Kenyans "should construe themselves as distinctive ethnic or 'tribal' group, or downplay their distinctiveness from other Kenyans?" (pg.219). She concludes that through the self-segregation based on 'cultural differences' White Kenyans are in their sense belonging to their own 'tribe' which makes them more rather than less Kenyan - yet they are quick to dismiss this sense of ethno tribalism when it benefits them. This book illustrates, that Black Kenyans believe that the descriptor of 'African' is harder to earn for the White Kenyans and Black Kenyans are skeptical - partly class based and partly race based - on their 'belonging' in the Kenyan nation. It seems to be that White Kenyans remain stuck between their "struggle with the simultaneity of wishing to connect with Black Kenyans and their lingering residues of felt superiority and aversions to certain African lifeway's" (pg.223).
This book offers a great insight into the field of social anthropology as it is not only informative about the sometimes erased or forgotten colonial history of Kenya, but through her ethnographic account of her time spent in Kenya and her discussion of language and identity, the author gives the reader insight into the lives and ideologies of her respondents. We are able to see that they act and justify their position in the world through complex, internally fraught frameworks of meaning, rather than the sheer malice or simple greed which is beneficial to those in the field of social and applied linguistics.

\section{Carla Roets}

\section{University of the Western}

Cape 